\title{
半導体レーザーを用いたコンタクトレーザーメスの開発
}

鎮西恒雄、阿部裕輔*、米沢卓実*、鈴川正之*、河野明正*、
小野俊哉*、満㴊邦彦、井街 宏*、渥美和彦*、藤正 䈨

東京大学先端科学技術研究センター

*東京大学医学部医用電子研究施設

\section{Development of Contact Laser Scalpel with High power Semiconductor Laser}

T. Chinzei, Y. Abe*, T. Yonezawa*, M.Suzukawa*, A.Kouno*, T.Ono*, K.Mabuchi, K. Imachi*, K. Atsumi*, I. Fujimasa Research Center for Advanced Science and Technology, The University of Tokyo *Institute of Medical Electronics, Faculty of Medicine, University of Tokyo

We developed contact laser scalpel with high power semiconductor laser for surgical operation. Output power of this equipment was $4.5 \mathrm{~W}$ maximum at the fiber end. This compact laser equipment (W300xD500xH330mm) was operated with 100VAC (900VA, air-cooled).

The laser unit consisted of $4 \mathrm{CW}$ laser diode. First, laser beam was superimposed together using difference of polarization and wave length. Next, laser beam was collimated and introduced to $400 \mu$ quartz fiber (NA 0.37). At the end of the fiber, a sapphire surgical rod with metal implantation was attached to convert laser power to heat effectively.

Incision and coagulation was performed with this equipment on abdominal skin with muscle tissue, cartilage of femoral joint and liver of rabbits under anesthesia. The operation was performed easily in all cases and bleeding was controlled with additional cauterization for several second. Histological finding showed that sharp surgical rod gave best incision surface.

\section{[はじめに]}

レーザー装置を手術室へ導入する際、1)重量、 サイズ、2)電源、3)冷却水、4)ガス供給、排気系 などの点が問題となる。これらの問題点に回答を 与えるレーザー素子として、半導体レーザー繋子 が注目を集めている。われわれは、以前、単一の
半導体レーザー素子を用いた高効率小型のレーザ 一手術装置を開発し、マイクロサージェリ用レー ザー装置として発表した1)。本報告では、複数の 半導体レーザー素子を集積し高レーザー出力を得 た装置に関し報告する。本装置により、半導体レ 一ザー素子の応用分野を通常の外科手術にまで広 げることが可能であることが示された。

\section{[装置の構成］}

装置の概観を図 1 に示す。装置は装置本体、 レーザーファイバ、ハンドピースで構成される。 渂置の仕椂を表 1 に示す。本装置では、4 素子の 連続発振半導体レーザー光出力を合成し、0-4. $5 \mathrm{~W}$ (0.1Wステップ可変) のファイバ端出力 を得ている。レーザー素子はペルチエによる電子 冷却を介して空冷され、水冷は用いていない。電 源は通常の商用電源 (AC $100 \mathrm{~V} 、 900 \mathrm{VA}$ ) を用いている。装置の大きさ、重量とも電気メス をやや上回る程度であり、手術室への設置も容易 である。

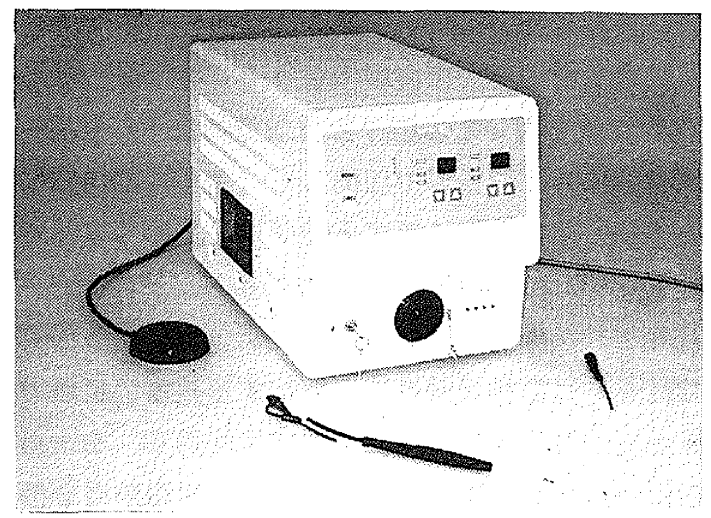

図 1 高出力半導体レーザー装置 
合波ユニットの構成を図 2 に示す。合波ユニ ットは偏光、波長の違いを利用して 4 素子の半導 体レーザーの出力を合成する。半導体レーザー素 子からのレーザー光はシリンドリカルレンズを用 いてタイバージェンシを補正される。それぞれ、 $\mathrm{P}, \mathrm{S}$ の偏光をもったレーザー光をビームスプリ ッタを用いて合波する。この 2 素子合波ユニット を波長を違えて（730 n m、830 n m) 2 組 用意し、これらの出力をタイクロイックミラーを 用いて合波する。こうして合波された 4 素子のレ 一ザー出力をレンズを用いて光ファイバーへ集光 する。光ファイバはコア径400 $4 \mathrm{~m} 、 \mathrm{NAO}$.

37 の石英ファイバを用いた。半導体レーザー素 子および合波ユニットはSONY（株）により開 発されたものである。

サージカルロッドの外観を図 3 に示す。サー ジカルロッドはいずれも人工サファイアを研磨成 形し、先端に金属をインプラントしたものである。 サージカルロッドの形状は効率よく先端にレーザ 一光を集光できるよう選ばれた。また、先端の金 属インプラントはレーザー出力を有効に熱に変掺 するとともに、組織への不用なレーザー光の漏洩 を防ぐ効果がある。インプラント法は基材表層中 に金属原子が打ち込まれるため、蒸着あるいはス パッタによる金属膜形成に比べ強い膜接着強度が 得られる。

\section{[生体組織での評価］}

家鬼を用い、本装置の性能を肉眼的、組織学 的に検討した。

\section{1.腹壁の切開、止血凝固}

本装置を用いて麻醉下家鬼腹壁の皮下、筋層 組織を出力 4.5Wで切開した（図 4)。切開創 約 $10 \mathrm{~cm}$ の切開に要する時間は平均約 20 秒で あり、電気入スに比較してやや所用時間が長いが、 スムーズな操作が可能であった。一部の出血部位 ではさらに数秒接触焼灼を追加することで止血で きた。組織標本では、切開端で平均約 $0.1 \mathrm{~mm}$ の薄い炭化層、平均約 $0.4 \mathrm{~mm}$ の熱融解層を伴 う熱変性層が観察された（図５）。熱変性層は電
表 1 装置の仕様

レーザーダイオード $830 / 780 \mathrm{~nm} 2$ 波長合成 レーザー出力 $0-4.5 W$ (ファイバー先端)

導光

プローブ長 $400 \mu \mathrm{m}$ 石英ファイバー

消費電力 $300 \mathrm{~mm}$

本体寸法

本体重量 W300 x D500 x H330 mm $26 \mathrm{~kg}$

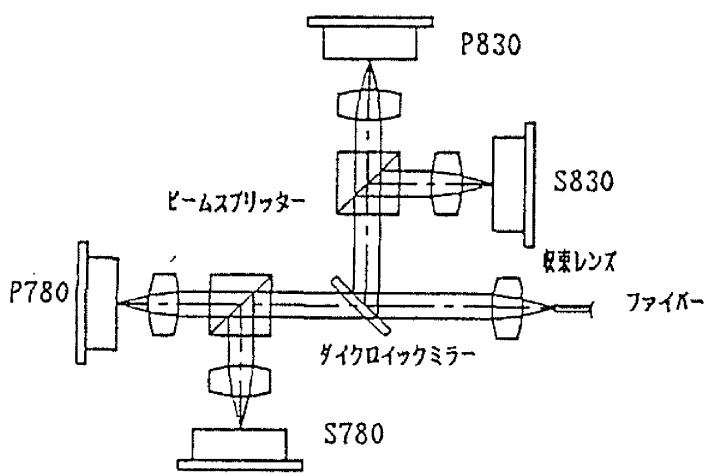

図 2 合波ユニット基本概念図

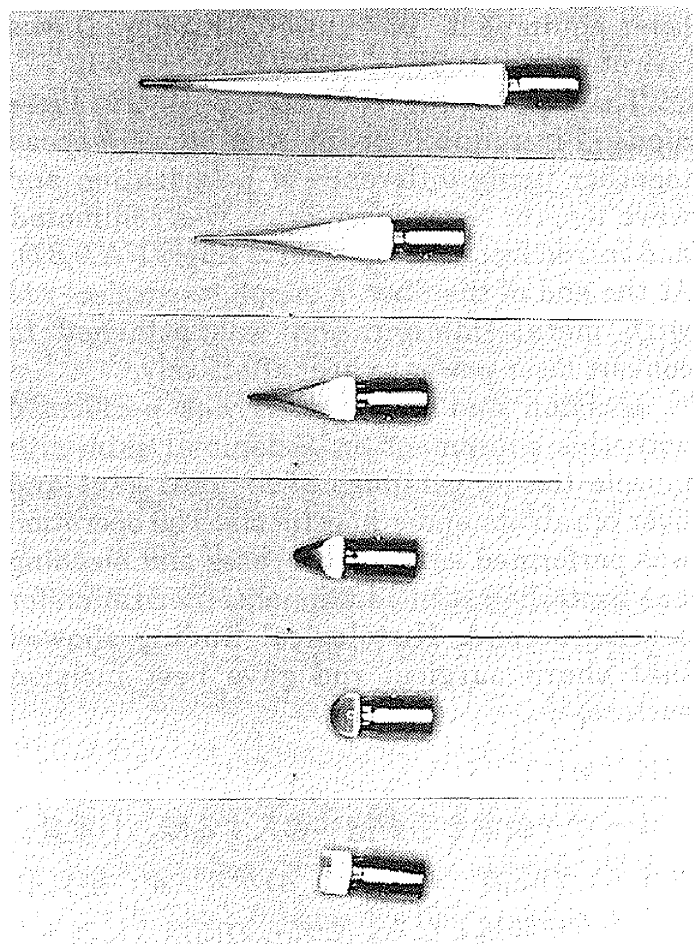

図 3 先端に金属膜をインプラントしたサファイ アチップ 

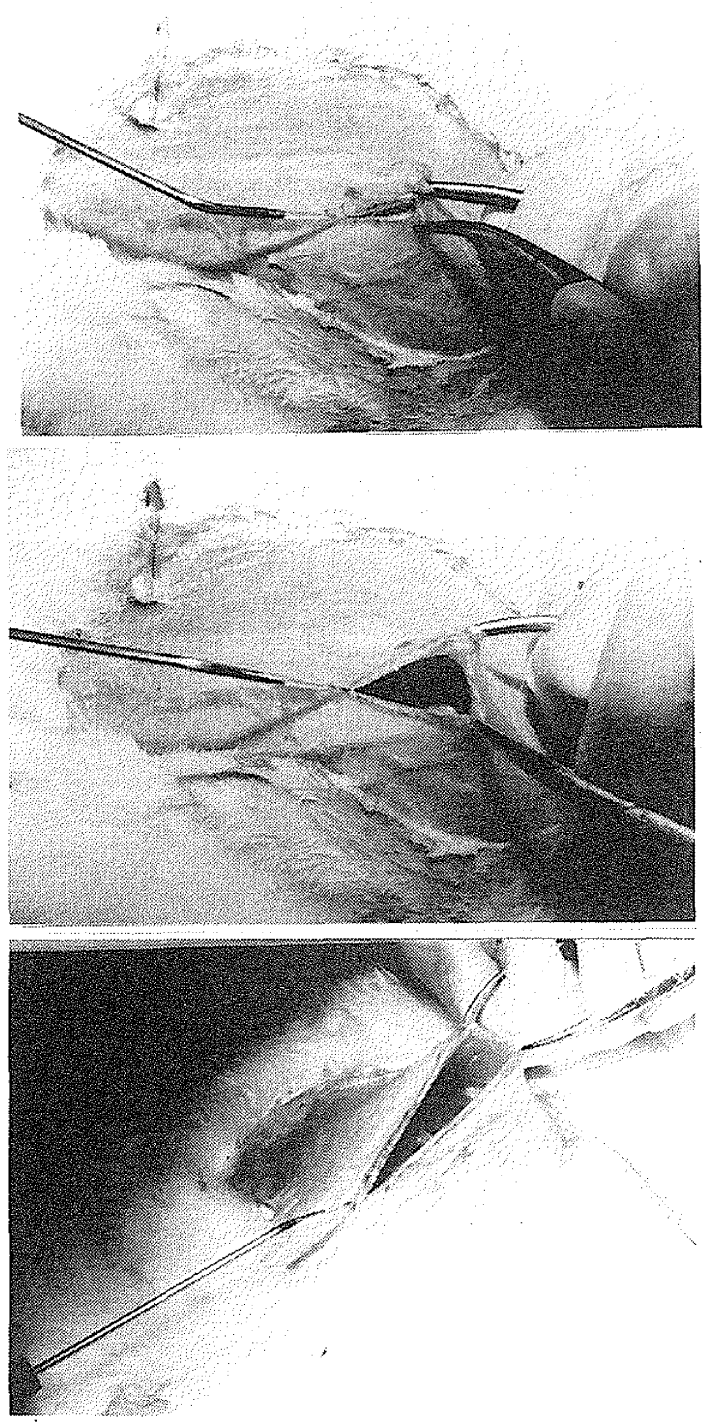

図 4 家鬼腹壁の切開

気メスに比較して薄く、連続発振Y A Gレーザー によるコンタクトレーザーメスとほは同等の厚さ であった。

\section{2 . 瑱骨面の焼灼}

家兔股関節軟骨面を出力 4.5 Wで焼灼した。 組織像では、薄い炭化層を伴う軽度の熱变性層が 観察された（図 6)。

3. 肝表面の切開、止血凝固

家兔肝表面を出力 4.5 Wで切開した（図 7）。 図では上下 2 本の切開創が示されている。上方の

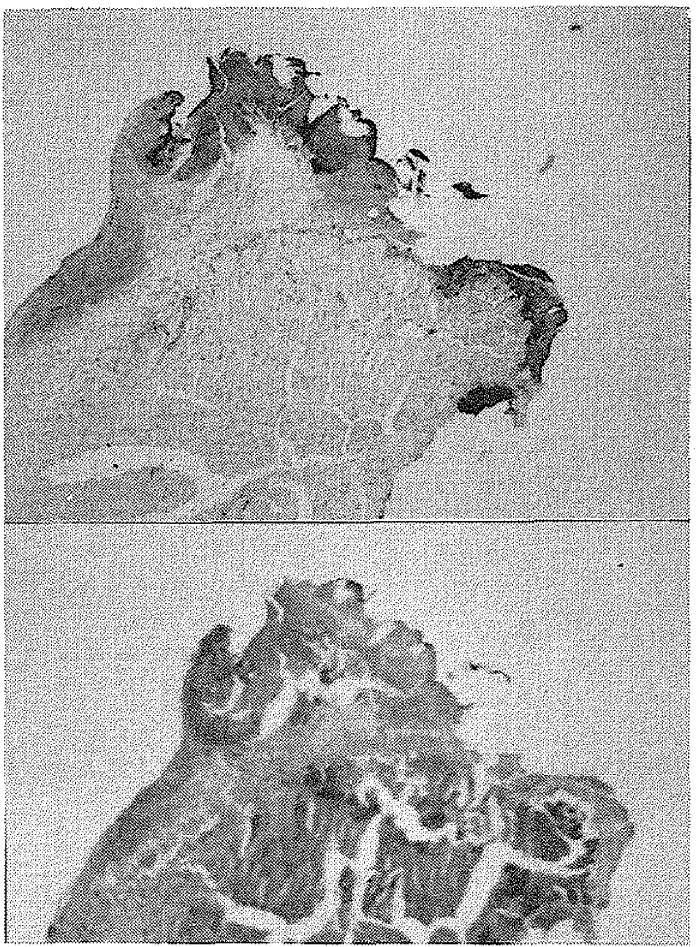

図 5 腹壁皮下、筋層切断面

切開創は、図 3 で示したサージカルロッドのうち 最も鋭利なものを用いて得たものである。下方の 切開創では先端が半球形のサージカルロッドを用 いた。いずれの切開創でも止血不能な出血はなか つた。組織像では、先端が鋭利なサージカルロッ ドを用いた例では、炭化層、熱融解層が比較的薄 く、良好な切開面が得られた（図 8 上）。逆に先 端が半球形の+ージカルロッドを用いた例では、 熱が拡散し、高度熟変性層が広い範囲に見られた （図８下）。サージカルロッドの形状は効率よく 先端にレーザー光を集光できる先端が鋭利な形状 が最も適していることが判った。

\section{[結語]}

以上、本装置は、一般の外科手術用レーザー メスとしてほほ渵足すべき性能を持つことが実証 された。電気メスと同等な切開、凝固性能を满た すには、連続発振Y A G レーザーでは本装㧽と同 样なサージカルロッドを用いて約 8〜10 W程度 のレーザー出力が必要である。従って、本装置で 


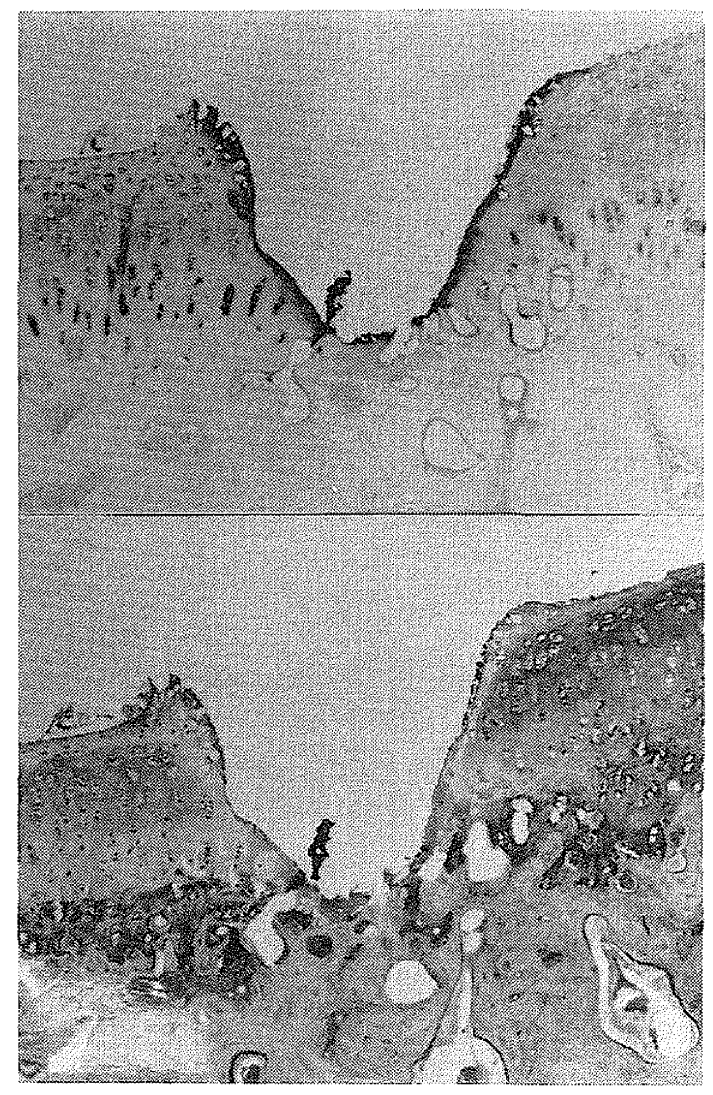

図 6 軟骨の焼灼像

も 8〜10W程度までレーザー出力を引き上げる 必琶があると思われる。現在、合波ユニット、フ アイバ入射端への集光部、サージカルロッドなど 光伝達損失の多い部分の改良を行い、さらに高光 出力が得られるよう開発を進めている。

\section{[まとめ]}

1. 小型高出力半導体レーザー手術装置を開発し た。

2、本装置は、皮下、筋層、軟骨、肝など各葴器 で迅速な切開が行え、また止血も十分であっ た。

3. 先端が鋭利なサージカルロッドを用いた例で は、炭化層、熱融解層が比較的薄く、良好な 切開面が得られた。逆に先端が半球形のサー ジカルロッドを用いた例では、熟が拡散し、 高度熱变性層が広い範囲に見られた。

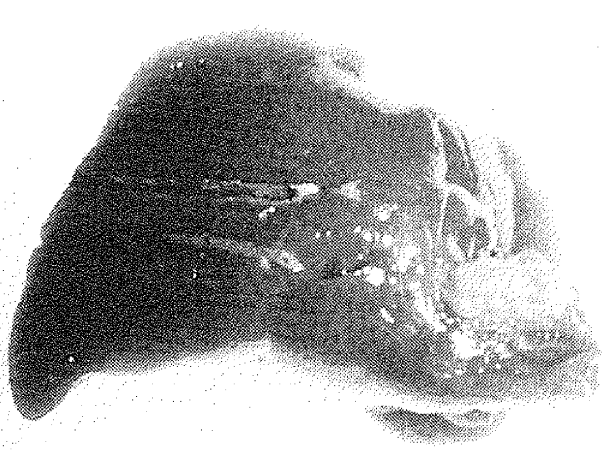

図 7 肝表面の切開、止血凝固

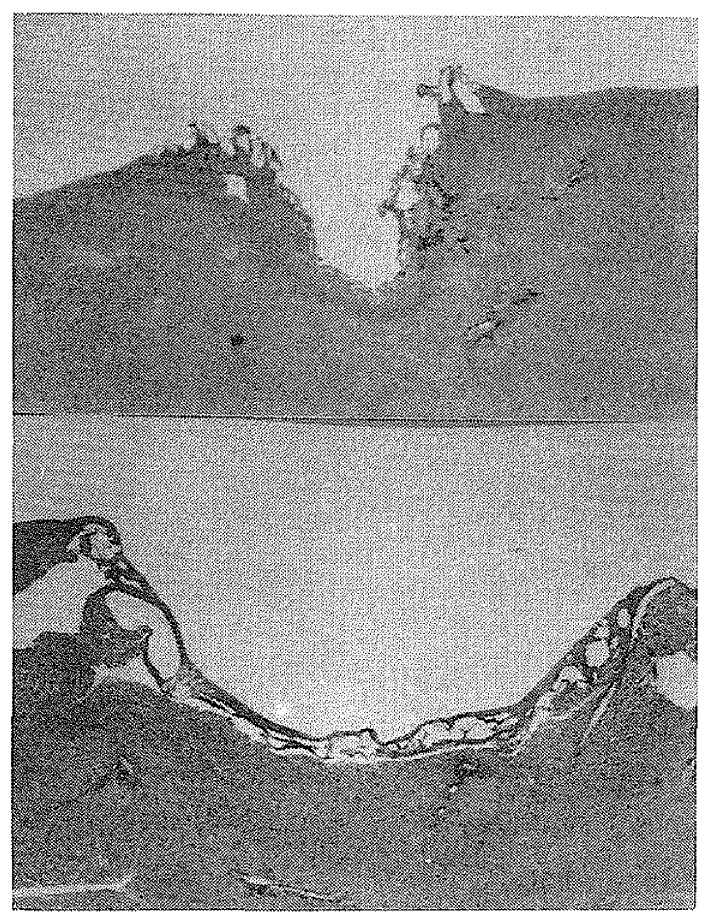

図 8 肝表面の熱変性層 尖鋭なチップ（上）と 鈍なチップ（下）による相違

\section{謝辞}

本装置の開発にあたり、協力をいただきまし た長田電気工業株式会社、ソニー株式会社に深謝 いたします。

[文献]

1)鎮西恒雄、阿部裕韩、米沢卓実、他：マイクロ サージェリーのための半導体レーザー装置の開発 日本レーザー医学会誌 9(3)、p387-390、1988 